\begin{tabular}{|c|c|c|c|}
\hline \multirow{3}{*}{$\begin{array}{r}\text { Case Reports in } \\
\text { Gastroenterology }\end{array}$} & \multicolumn{2}{|c|}{ Case Rep Gastroenterol 2014;8:82-88 } & \multirow[b]{2}{*}{$\begin{array}{l}\text { Karger } \\
\text { Opengaccess }\end{array}$} \\
\hline & $\begin{array}{l}\text { DOI: 10.1159/000360846 } \\
\text { Publisned onIne: Vvarch 19, } 2014\end{array}$ & $\begin{array}{l}\text { (c) } 2014 \text { S. Karger AG, Basel } \\
1662-0631 / 14 / 0081-0082 \$ 39.50 / 0 \\
\text { www.karger.com/crg }\end{array}$ & \\
\hline & $\begin{array}{l}\text { This is an Open Access article license } \\
\text { NonCommercial } 3.0 \text { Unported licens } \\
\text { the online version of the article only. }\end{array}$ & $\begin{array}{l}\text { s of the Creative Commons Attribution } \\
\text { w.karger.com/OA-license), applicable t } \\
\text { tted for non-commercial purposes only. }\end{array}$ & \\
\hline
\end{tabular}

\title{
Successful Colectomy for Hemorrhagic Colitis with Hemolytic Uremic Syndrome and Acute Encephalopathy due to Escherichia coli 0157 Infection
}

\author{
Tetsuro Tominaga $^{a}$ Masahiro Oikawa $^{a}$ Hiroaki Takeshita $^{a}$ \\ Masaki Kunizaki $^{a}$ Kazuo Tou $^{\mathrm{a}}$ Takafumi Abo $^{\mathrm{a}}$ Shigekazu Hidaka $^{\mathrm{a}}$ \\ Atsushi Nanashima ${ }^{a}$ Terumitsu Sawai ${ }^{b}$ Takeshi Nagayasu ${ }^{a}$ \\ ${ }^{a}$ Division of Surgical Oncology, Department of Surgery, Nagasaki University Graduate \\ School of Biomedical Science, and ${ }^{b}$ Nagasaki University School of Health Science, \\ Nagasaki, Japan
}

\section{Key Words \\ Escherichia coli $\mathrm{O} 157 \cdot$ Hemolytic uremic syndrome · Colectomy}

\begin{abstract}
An 81-year-old man was admitted to a primary care hospital due to bloody diarrhea. The findings of abdominal computed tomography indicated ischemic colitis, so conservative therapy was started. On the 4th hospital day, the patient was transferred to our hospital because of renal dysfunction. Physical examination showed clouding of consciousness and abdominal distention. Abdominal computed tomography revealed massive ascites and thickening of the whole colonic wall. With a diagnosis of acute abdomen, an emergent laparotomy was performed. Extended right hemicolectomy was performed because of severe ischemic change and necrosis of the right side of the colon. In the stool culture before the operation, Escherichia coli $\mathrm{O} 157$ and verotoxin were found, so this case was diagnosed as hemorrhagic colitis with hemolytic uremic syndrome and acute encephalopathy due to Escherichia coli 0157 infection. Postoperatively, the hemolytic uremic syndrome and acute encephalopathy were prolonged. However, with intensive care, the patient recovered and was discharged on the 33rd postoperative day.

(c) 2014 S. Karger AG, Basel
\end{abstract}


Tominaga et al.: Successful Colectomy for Hemorrhagic Colitis with Hemolytic Uremic Syndrome and Acute Encephalopathy due to Escherichia coli O157 Infection

\section{Introduction}

Escherichia coli 0157 (0157) is a serious human pathogen that causes severe enterocolitis by producing verotoxin [1]. It is sometimes complicated by hemolytic uremic syndrome (HUS) or acute encephalopathy, which results in a poor prognosis [2]. Ordinarily, management of the disease is mainly supportive care, and there have been few surgical cases reported [3]. A rare case of successful colectomy for hemorrhagic colitis with HUS and acute encephalopathy due to 0157 infection is reported.

\section{Case Presentation}

An 81-year-old man was admitted to a primary hospital with complaints of lower abdominal pain and bloody diarrhea. He had no specific past medical history. Abdominal computed tomography revealed thickness of the descending colon wall. He was given intravenous hydration and antibiotic therapy (cefotiam, levofloxacin) with a diagnosis of ischemic colitis. On hospital day 2, follow-up abdominal computed tomography showed ascites and thickness of the entire colon wall. On hospital day 4, the patient was transferred to our hospital because of renal dysfunction and a convulsion. In the first aid station, the patient's consciousness was slightly clouded; temperature was $38.0^{\circ} \mathrm{C}$, blood pressure 140/92 $\mathrm{mm} \mathrm{Hg}$ and heart rate 95/min. His skin was cold and moist. The abdomen was distended and tympanic, with generalized tenderness. Laboratory studies revealed severe inflammation, anemia, a low platelet count and renal dysfunction. Blood gas analysis showed hypoxemia, metabolic acidosis and a low $\mathrm{CO}_{2}$ level due to tachypnea. Colonoscopy revealed diffuse mucosal edema, ulcer formation and bleeding from the rectum to the ascending colon (fig. 1a, b). There was no evidence of free air, but the whole colon wall was markedly thickened, with huge ascites on abdominal computed tomography (fig. 1c). Gradually, the patient's vital signs deteriorated (blood pressure 60/40 $\mathrm{mm} \mathrm{Hg}$, heart rate $115 / \mathrm{min}$ ), with severe disturbance of consciousness, and generalized cyanosis could be seen. He was diagnosed as having necrotic ischemic colitis with septic shock and underwent emergency surgery. The operative findings showed a large amount of ascites. From the rectum to the cecum, the colon wall was markedly edematous and sclerotic. In particular, inflammation of the transverse colon extended to the greater omentum with necrosis. An extended right hemicolectomy and ileostomy were performed. The resected specimen showed hemorrhagic necrosis of the transverse colon (fig. 2). Pathological findings showed mucosal hemorrhagic necrosis with submucosal edema. There was venous dilatation and congestion of blood, which suggested ischemic colitis. In the stool culture before the operation, 0157 and verotoxin were found. This case was therefore diagnosed as hemorrhagic colitis with HUS and acute encephalopathy due to 0157 infection. After the operation, the patient was treated in the intensive care unit with ventilation because of delayed emergence from anesthesia due to encephalopathy and poor oxygenation. However, with intensive care, the HUS and encephalopathy improved gradually without dialysis. He was finally discharged on the 33rd postoperative day (fig. 3).

\section{Discussion}

In 1977, Konowalchuk first reported a case of 0157-induced colitis, and this bacterium has been recognized as a serious human pathogen that causes severe gastroenteritis by 
Tominaga et al.: Successful Colectomy for Hemorrhagic Colitis with Hemolytic Uremic Syndrome and Acute Encephalopathy due to Escherichia coli O157 Infection

producing verotoxin [1]. The criteria for making a diagnosis of 0157 infection include (1) detection of 0157 bacterial cells from cultured stool specimens, (2) detection of verotoxin from stool, and (3) confirmation of an elevation of 0157 antibody titer in the blood [4]. However, a few days are needed to confirm the diagnosis. In the present case, 0157 was detected from a stool specimen 2 days after onset. A recent report described a fast and sensitive enzyme-linked immunosorbent assay method to measure 0157 bacteria within a few hours [5]. It may be an alternative method to help diagnose and treat this serious disease faster in the future.

In $10-15 \%$ of patients with verotoxin-produced 0157 colitis, HUS was seen [2]. HUS usually develops 5-13 days after the onset of diarrhea. Furthermore, HUS patients usually develop encephalopathy, which leads to a poor prognosis [3]. The pathogenesis involves the verotoxin produced by 0157 binding to the receptors on renal tubular epithelial cells and the vascular endothelial cells of the kidney or brain [2]. Typically, the diagnosis of HUS is confirmed by thrombocytopenia, hemolytic anemia and acute renal failure. The present patient fulfilled these criteria, so that he was finally diagnosed as having severe HUS with acute encephalopathy.

Teramoto et al. [6] retrospectively analyzed the clinical records of patients with 0157induced HUS and evaluated the correlations between laboratory data and disease severity. The CRP and WBC levels were high and the serum Na and total protein levels were low in severe HUS patients with encephalopathy. They created an SCWP (sodium, CRP, WBC count and total protein) score using these four factors to predict increasing severity: (1) CRP (mg/dl) - score 0, <0.5; score 1, 0.5-<1.0; score 2, 1.0-<2.0; score 3, $\geq 2.0$. (2) Na (mEq/l) score 0 , >136; score 1, 132-136; score 2, 127-131; score 3, $\leq 126$. (3) Total protein (g/dl) score 0 , >6.5; score 1, 5.8-6.5; score 2, 4.9-5.7; score 3, $\leq 4.8$. (4) WBC $(/ \mu \mathrm{l})$ - score $0,<9,200$; score 1, 9,200-<12,100; score 2, 12,100-15,000; score $3,>15,000$. The average score of the severe HUS group was 10 (from 9 to 11), compared to 5 (from 2 to 7) in the mild cases group, and they suggested that this score may be useful to predict a high risk of severe HUS. In the present severe HUS case with encephalopathy, the SCWP score was 9.

The main treatment of this disease is medical treatment including fluid replacement, antibiotics and dialysis. However, as in the present case, surgical treatment is required for rescue when severe colitis develops [3]. Sepsis induced by necrotic colitis leads to elevated serum levels of inflammatory cytokines and systemic damage to vascular endothelial cells [7]. In fact, Whitington et al. [8] reported that colon necrosis caused prolonged HUS, which finally increased mortality. Therefore, it is important to perform surgery appropriately when colon necrosis is suspected, as in the present case.

Table 1 reviews 8 Japanese cases of 0157 that required surgical treatment [9-15]. In the review, none of the cases was definitively diagnosed as having 0157-related colitis preoperatively. Most patients underwent emergency surgery due to evidence of peritonitis on physical examination. In many cases, inflammation involved mainly the right colon, and right hemicolectomy was performed. However, in the present case, since the inflammation spread to involve the whole colon, subtotal colectomy was needed. As all of the colectomy cases showed colon necrosis or perforation in the resected specimens, surgical therapy was critical for rescue. Six of eight patients (75\%) developed HUS, and three cases developed encephalopathy. The average SCWP score of patients with HUS was 7.5 compared with 4 for those without HUS. One patient died due to multiple organ failure.

In conclusion, appropriate surgery is needed when colon necrosis is suspected to prevent disease progression. 


\begin{tabular}{l|l}
\hline \multicolumn{2}{l}{ Case Rep Gastroenterol 2014;8:82-88 } \\
\hline DOI: $10.1159 / 000360846$ & $\begin{array}{l}\text { C 2014 S. Karger AG, Basel } \\
\text { www.karger.com/crg }\end{array}$ \\
\hline
\end{tabular}

Tominaga et al.: Successful Colectomy for Hemorrhagic Colitis with Hemolytic Uremic Syndrome and Acute Encephalopathy due to Escherichia coli O157 Infection

\section{Disclosure Statement}

The authors have no conflict of interest.

\section{References}

1 Rosensweig JN, Gourley GR: Verotoxic Escherichia coli in human disease. J Pediatr Gastroenterol Nutr $1991 ; 12: 295-304$.

$>2$ Tarr PI, Gordon CA, Chandler WL: Shiga-toxin-producing Escherichia coli and haemolytic uraemic syndrome. Lancet 2005;365:1073-1086.

$>3$ Tapper D, Tarr P, Avner E, Brandt J, Waldhausen J: Lessons learned in the management of hemolytic uremic syndrome in children. J Pediat Surg 1995;30:158-163.

4 Park CH, Gates KM, Vandel NM, Hixon DL: Isolation of Shiga-like toxin producing Escherichia coli (O157 and non-0157) in a community hospital. Diagn Microbiol Infect Dis 1996;26:69-72.

$\checkmark 5$ Park S, Min J, Kim YK: Chemiluminescent enzyme-linked immunosorbent assay on a strip to detect Escherichia coli 0157:H7. Int J Environ Anal Chem 2012;92:655-664.

-6 Teramoto T, Fukao T, Hirayama K, Asano T, Aoki Y, Kondo N: Escherichia coli 0-157-induced hemolytic uremic syndrome: usefulness of SCWP score for the prediction of neurological complication. Pediatr Int 2009;51:107-109.

7 Dellinger RP, Levy MM, Rhodes A, Annane D, Gerlach H, Opal SM, Sevransky JE, Sprung CL, Douglas IS, Jaeschke R, Osborn TM, Nunnally ME, Townsend SR, Reinhart K, Kleinpell RM, Angus DC, Deutschman CS, Machado FR, Rubenfeld GD, Webb SA, Beale RJ, Vincent JL, Moreno R; Surviving Sepsis Campaign Guidelines Committee including the Pediatric Subgroup: Surviving sepsis campaign: international guidelines for management of severe sepsis and septic shock: 2012. Crit Care Med 2013;41:580-637.

$>8$ Whitington PF, Friedman AL, Chesney RW: Gastrointestinal disease in the hemolytic-uremic syndrome. Gastroenterology 1979;76:728-733.

9 Kaku N, Takenaka S, Masumoto S: A critical case of hemolytic uremic syndrome due to 0-157 E-coli infection associated with perforated appendicitis, intraperitoneal abscess, volvulus of the transverse colon, and pulmonary edema, successfully treated with long-term continuous hemodiafiltration (in Japanese with English abstract). Jpn J Pediatr 2008;61:473-477.

10 Maruyama K, Yamasaki Y, Uchida K: A case of successful colectomy for hemorrhagic colitis with hemolytic uremic syndrome, due to Escherichia coli 0-157 infection (in Japanese with English abstract). Jpn J Gastroenterol Surg 2004;37:334-338.

11 Hoashi T, Iwase K, Higaki J, Yoon HE, Mikata S, Miyazaki M, Nishitani A, Kawamoto K, Oimatsu N, Kin K, Imakita M, Kamiike W: A case of colitis caused by enterohemorrhagic Escherichia coli 0-157:H7, requiring surgery for concomitant peritonitis (in Japanese with English abstract). J Abdom Emerg Med 2002;22:979983.

-12 Ishida Y, Kobayashi S, Hara A, Yamazaki Y, Aoki T: A case report of Escherichia coli 0157 infection, which was difficult to discriminate from intussusception (in Japanese with English abstract). Jpn J Gastroenterol Surg 2001;34:259-262.

13 Tamiya Y, Tsujimoto S, Hamatani S, Mitsuda A, Hasegawa C, Yanagita M, Tokura N, Hattori T: A pathological study on the surgical specimen of E. coli 0157:H7-associated colitis (in Japanese with English abstract). J Jpn Soc Coloproctol 2000;53:156-161.

14 Seki Y, Maruyama K, Shimoda M: A case of hemolytic-uremic syndrome complicated with gangrenous colitis. J Pediatr Pract 1992;45:1271-1274.

15 Nakagawa J, Toyooka S, Hayashi M, Kawase M, Mukaino S, Hirose Y, Tanaka T, Tanabe T, Nishikawa K, Sagou T: A case of adult hemolytic-uremic syndrome with Escherichia coli 0157 infections (in Japanese with English abstract). Nihon Shokakibyo Gakkai Zasshi 1998;95:41-45. 
Tominaga et al.: Successful Colectomy for Hemorrhagic Colitis with Hemolytic Uremic Syndrome and Acute Encephalopathy due to Escherichia coli 0157 Infection

Table 1. Review of cases reported in the Japanese literature of patients who underwent resection due to $E$. coli infection

\begin{tabular}{|c|c|c|c|c|c|c|c|c|c|}
\hline $\begin{array}{l}\text { Reference } \\
\text { (first author) }\end{array}$ & $\begin{array}{l}\text { Age, } \\
\text { years }\end{array}$ & Sex & $\begin{array}{l}\text { Preoperative } \\
\text { diagnosis }\end{array}$ & $\begin{array}{l}\text { Indication for } \\
\text { resection }\end{array}$ & Operation & HUS & $\begin{array}{l}\text { Enceph- } \\
\text { alopathy }\end{array}$ & $\begin{array}{l}\text { SCWP } \\
\text { score }\end{array}$ & Outcome \\
\hline Kaku, 2008 [9] & 6 & M & $\begin{array}{l}\text { abdominal } \\
\text { abscess }\end{array}$ & peritonitis & abscess drainage & + & - & 6 & alive \\
\hline $\begin{array}{l}\text { Maruyama, } \\
2004[10]\end{array}$ & 58 & $\mathrm{~F}$ & $\begin{array}{l}\text { hemorrhagic } \\
\text { colitis }\end{array}$ & peritonitis & $\begin{array}{l}\text { extended right } \\
\text { hemicolectomy, ileostomy }\end{array}$ & + & - & 8 & alive \\
\hline $\begin{array}{l}\text { Hoashi, } 2002 \\
\text { [11] }\end{array}$ & 61 & $\mathrm{~F}$ & bacterial colitis & peritonitis & $\begin{array}{l}\text { right hemicolectomy, } \\
\text { ileostomy }\end{array}$ & - & - & 5 & alive \\
\hline $\begin{array}{l}\text { Ishida, } 2001 \\
{[12]}\end{array}$ & 20 & $\mathrm{~F}$ & intussusception & intussusception & appendectomy & - & - & 3 & alive \\
\hline $\begin{array}{l}\text { Tamiya, } 2000 \\
\text { [13] }\end{array}$ & 72 & $\mathrm{~F}$ & ischemic colitis & peritonitis & $\begin{array}{l}\text { extended right } \\
\text { hemicolectomy, ileostomy }\end{array}$ & + & - & 7 & $\begin{array}{l}\text { died } \\
\text { (5 months) }\end{array}$ \\
\hline Seki, 1992 [14] & 4 & $\mathrm{~F}$ & $\begin{array}{l}\text { acute renal } \\
\text { failure }\end{array}$ & peritonitis & $\begin{array}{l}\text { extended right } \\
\text { hemicolectomy, ileostomy }\end{array}$ & + & + & - & alive \\
\hline $\begin{array}{l}\text { Nakagawa, } \\
1998[15]\end{array}$ & 33 & $\mathrm{~F}$ & necrotic colitis & peritonitis & left hemicolectomy & + & + & - & alive \\
\hline $\begin{array}{l}\text { Our case, } \\
2013\end{array}$ & 81 & M & ischemic colitis & peritonitis & $\begin{array}{l}\text { subtotal colectomy, } \\
\text { ileostomy }\end{array}$ & + & + & 9 & alive \\
\hline
\end{tabular}




\begin{tabular}{l|l}
\hline Case Rep Gastroenterol 2014;8:82-88 \\
\hline DOI: $10.1159 / 000360846$ & $\begin{array}{l}\text { ○ 2014 S. Karger AG, Basel } \\
\text { www.karger.com/crg }\end{array}$ \\
\hline
\end{tabular}

Tominaga et al.: Successful Colectomy for Hemorrhagic Colitis with Hemolytic Uremic Syndrome and Acute Encephalopathy due to Escherichia coli O157 Infection
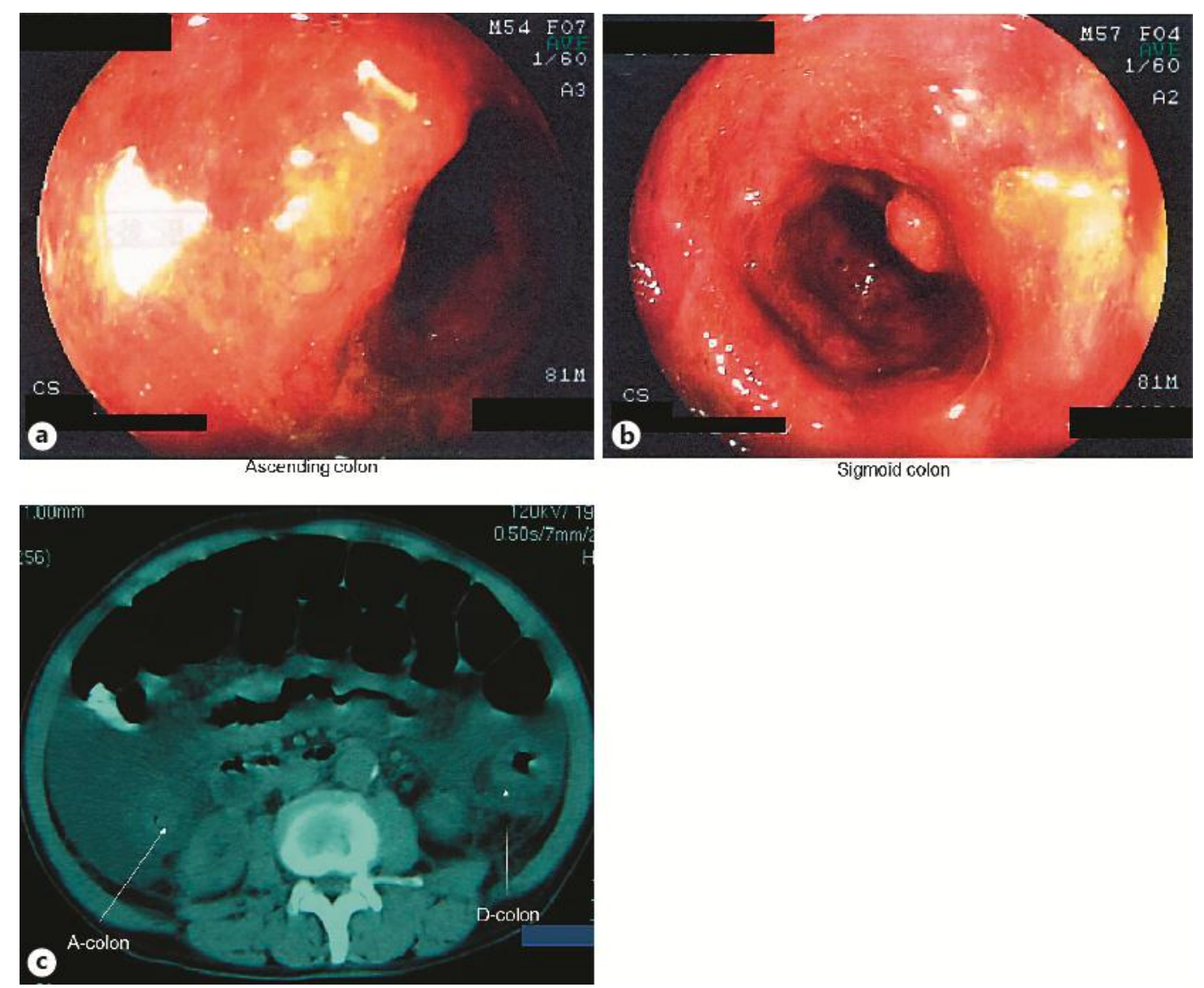

Fig. 1. Colonoscopy showed diffuse mucosal edema, ulcer formation and bleeding from the sigmoid colon (a) to the ascending colon (b). Abdominal computed tomography showed that the whole colon wall was markedly thickened, with huge ascites (c).

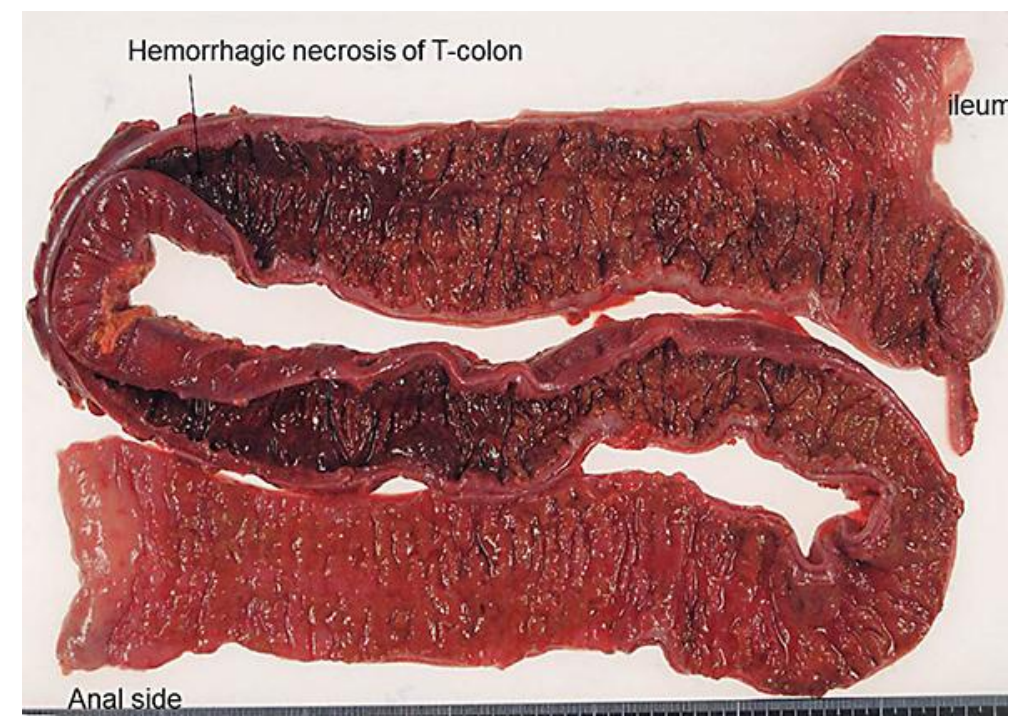

Fig. 2. The resected specimen showed hemorrhagic necrosis of the transverse colon. 
Tominaga et al.: Successful Colectomy for Hemorrhagic Colitis with Hemolytic Uremic Syndrome and Acute Encephalopathy due to Escherichia coli O157 Infection

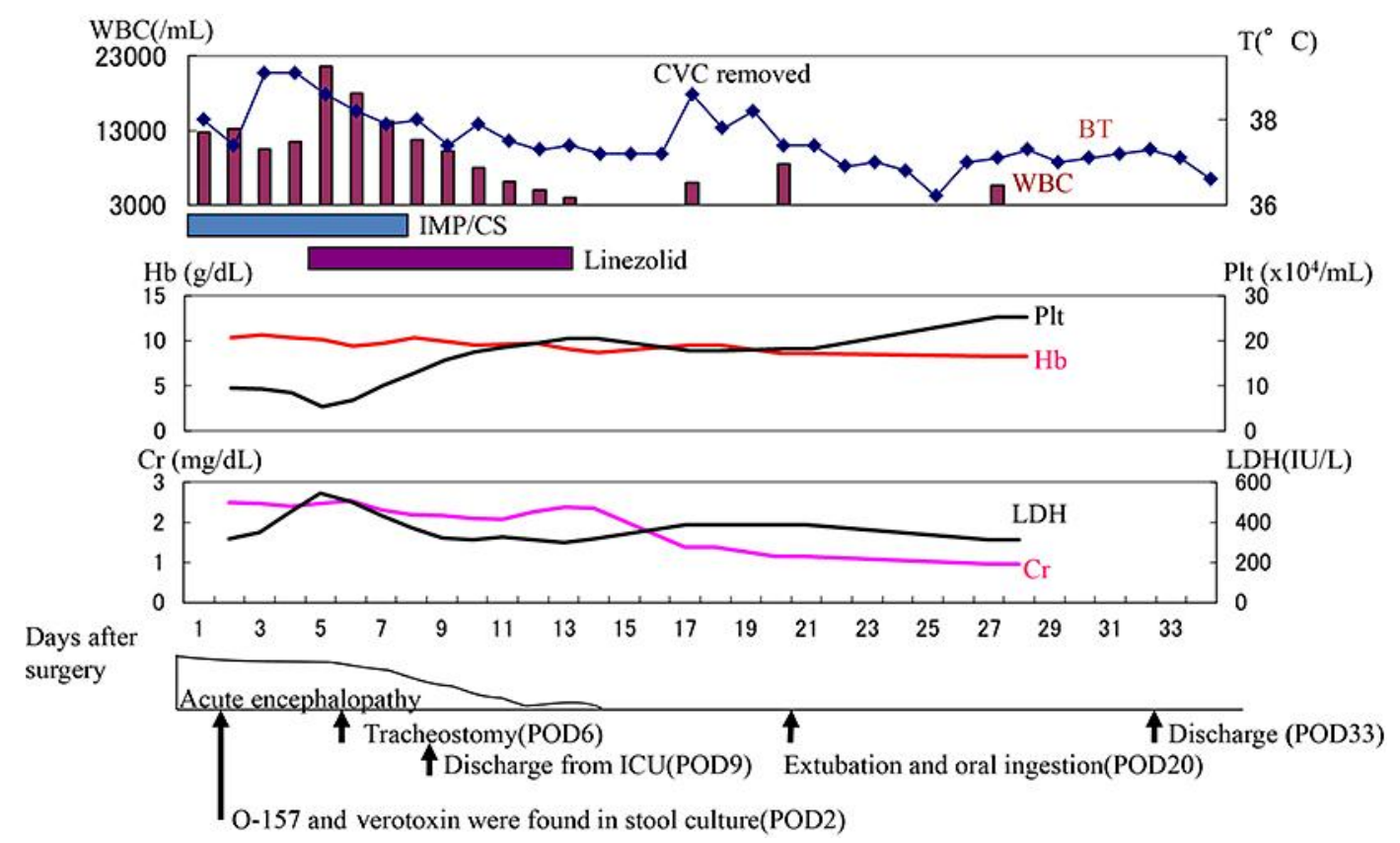

Fig. 3. Postoperative clinical course. 